Supporting Information (SI) for

\title{
Sustainable Lactic Acid Production from Lignocellulosic Biomass
}

\author{
Yalin $\mathrm{Li}^{1,2}$, Sarang S. Bhagwat ${ }^{2,3}$, Yoel R. Cortés-Peña ${ }^{2,3}$, Dongwon $\mathrm{Ki}^{1,2, \dagger}$, \\ Christopher V. Rao ${ }^{2,4}$, Yong-Su Jin ${ }^{2,5}$, Jeremy S. Guest ${ }^{1,2,3, *}$ \\ ${ }^{1}$ Institute for Sustainability, Energy, and Environment, University of Illinois at Urbana-Champaign, \\ 1101 W. Peabody Drive, Urbana, IL 61801, USA \\ ${ }^{2}$ DOE Center for Advanced Bioenergy and Bioproducts Innovation, University of Illinois at Urbana- \\ Champaign, 1206 W. Gregory Drive, Urbana, IL 61801, USA \\ ${ }^{3}$ Department of Civil and Environmental Engineering, University of Illinois at Urbana-Champaign, \\ 3221 Newmark Civil Engineering Laboratory, 205 N. Mathews Avenue, Urbana, IL 61801, USA \\ ${ }^{4}$ Department of Chemical and Biomolecular Engineering, University of Illinois at Urbana- \\ Champaign, 114 Roger Adams Laboratory, 600 S. Mathews Avenue, Urbana, IL 61801, USA \\ ${ }^{5}$ Department of Food Science and Human Nutrition, University of Illinois at Urbana-Champaign, \\ 260 Bevier Hall, 905 S. Goodwin Avenue, Urbana, IL 61801, USA \\ *Corresponding author. Phone: +1 (217) 244-9247; Email: jsguest@illinois.edu \\ ${ }^{\dagger}$ Present address: Division of Living and Built Environment Research, Seoul Institute of \\ Technology, 8F Maebongsan-ro 37, Mapo-gu, Seoul 03909, Republic of Korea
}

Number of pages: 22

Number of figures: 8

Number of tables: 5 


\section{Table of Contents}

Section S1. Supplementary Process Description and Analysis Methods ..............S3

Section S1.1. Conversion Process ................................................................................. S3

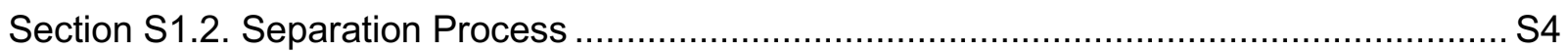

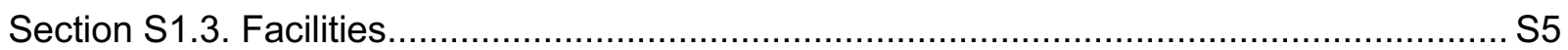

Section S1.4. Selection of Uncertainty Distributions ....................................................... S5

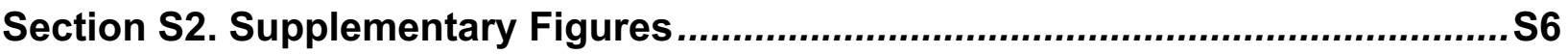

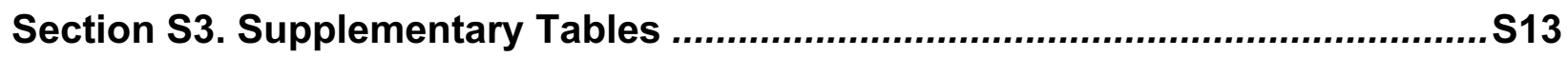

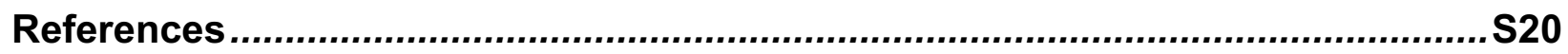

\section{List of Figures}

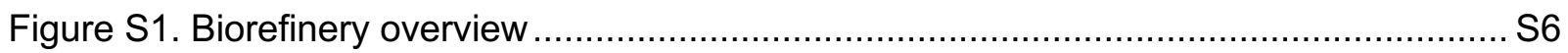

Figure S2. Titer, yield, and productivity of lactic acid fermentation....................................S7

Figure S3. Pinch diagram for the heat exchanger network........................................... S8

Figure S4. MPSP at different IRRs and comparison with literature .................................. 9

Figure S5. Improvement of MPSP, GWP 100 , and FEC under different assumptions ...............S9

Figure S6. Spearman's $\rho$ values and changes of sustainability indicators with input parameters

Figure S7. MPSP, GWP ${ }_{100}$, and FEC across the titer-yield performance space at the minimum productivity

Figure S8. MPSP, GWP ${ }_{100}$, and FEC across the titer-yield performance space at the maximum productivity S12

\section{List of Tables}

Table S1. List of major units and equipment included in the biorefinery (separation process not included). S13

Table S2. List of major units and equipment included in the separation process .................S15

Table S3. Reference literature for design of saccharification and fermentation units........... S16

Table S4. Considerations for the choice of separation process.......................................... S17

Table S5. List of parameters included in the uncertainty analysis ..................................... 18 


\section{Section S1. Supplementary Process Description and Analysis Methods}

\section{S1.1. Conversion Process}

The conversion process includes a saccharification unit, a fermentation unit, a seed preparation unit, and auxiliary units for mixing, heat exchange, and seed holding. In the saccharification unit, enzyme (purchased from external sources at $\$ 6.16 \cdot \mathrm{kg}^{-1}$ protein ${ }^{1}$ ) is added at the loading of $10 \mathrm{mg}$ protein per $\mathrm{g}$ of cellulose to hydrolyze cellulose in the pretreated feedstock slurry into glucose, after which the saccharified stream is transferred to the fermentation unit with addition of the seed culture and corn steep liquor (CSL, to provide nutrients). In the neutral fermentation scenario, lime is added during fermentation to neutralize the produced acids (lactic acid and byproduct acetic acid), and the amount of lime is set to $110 \%$ of the theoretical 1:2 lime-to-monobasic acid molar ratio (e.g., 0.55 mole of lime for 1 mole of lactic or acetic acid). In the low-pH fermentation scenario, it is assumed that acid-resistant strains are used for fermentation, therefore lime addition is not needed. The target product from fermentation is L-(+)-lactic acid given its widespread use, ${ }^{2,3}$ but similar titer, yield, and productivities have been achieved for D-(-)-lactic acid as well (Figure S2).

Three conversion configurations (Figure 1A in the main text) are included to evaluate the biorefinery across all feasible combinations of fermentation titer and yield. For low titers, the saccharified stream is diluted in batch fermenters (Configuration 1); when sugar concentration in the saccharified stream is insufficient to achieve the titer at a given yield, a multi-effect evaporation unit is added after saccharification to concentrate the saccharified stream (Configuration 2); a switch from batch (lower capital and operating costs) to continuous fermentation is made when sugar concentration in the concentrated saccharified stream exceeds $220 \mathrm{~g} \cdot \mathrm{L}^{-1}$ (Kuo et al., ${ }^{4}$ the maximum sugar concentration in collected data) to avoid over-saccharinity (Configuration 3). Higher sugar concentration in the saccharified stream can be leveraged in the continuous mode as the steady-state sugar concentration in the fermenter is lower than that of the incoming saccharified stream (i.e., sugar in the influent will be instantly mixed within the fermenter, thus sugar concentration in the fermenter is lower than the influent). When the steady-state sugar concentration in the fermenter exceeds $220 \mathrm{~g} \cdot \mathrm{L}^{-1}$, the titer-yield combination is considered to be infeasible.

In Configuration 1, a retention time of $24 \mathrm{~h}$ is used for the saccharification tank given that saccharification can continue during fermentation, but a longer retention time of $84 \mathrm{~h}$ (based on Humbird et al. ${ }^{5}$ ) is used in Configurations 2 and 3 given that the solid/liquid separation and evaporation steps will terminate the saccharification reaction. This increase in saccharification time has a minimal $(<1 \%)$ effect on minimum product selling price (MPSP), 100-year global warming potential $\left(\mathrm{GWP}_{100}\right)$, and fossil energy consumption (FEC). Therefore, even if realizing simultaneous saccharification and co-fermentation is challenging due to differences in optimal conditions of these two reactions, retention time for the saccharification tank in Configuration 1 can be increased and conclusions from this study will not change. For the fermentation reaction, retention time of the fermenter in all configurations is determined by the designated titer and productivity.

For the baseline design, Configuration 1 was used without the addition of dilution water (i.e., sugar concentration was determined by upstream units and lactic acid fermentation yield) as this was the simplest configuration and avoided compounded titer-yield impacts to interfere with other factors (e.g., lower titer obscuring the importance of higher pretreatment efficacy). A comprehensive analysis on the fermentation unit across the titer-yield performance space at varying productivities was conducted separately. Experimental fermentation metrics (e.g., titer, yield, productivity) were used to guide the design of the conversion process (Figure S2, Table S3), which were collected from literature that (i) used lignocellulosic feedstocks and (ii) converted both glucose and xylose (i.e., realized co-fermentation) into lactic acid. 


\section{S1.2. Separation Process}

In the separation process (Figure 1B), solids (lignin, unutilized carbohydrates, etc.) in the fermentation broth are removed using a pressure filter modeled similarly to that described in Humbird et al. ${ }^{5}$ (step 1). Sulfuric acid is added to the filtrate in an acidulation tank to convert calcium lactate into lactic acid and gypsum $\left(\mathrm{CaSO}_{4}\right)$, the latter of which is filtered out in the subsequent gypsum filter (step 2). For the low-pH fermentation scenario, the acidulation reactor and gypsum filter are not included as the produced lactic acid is converted to calcium lactate in the fermenter.

Upon filtration, water and a large portion of volatile organics (acetic acid, furfural, and hydroxymethyl furfural) are evaporated out of the solution (step 3), and the crude lactic acid stream is directed to an esterification reactor where ethanol reacts with lactic acid to form the corresponding ester ethyl lactate in the presence of Amberlyst-15 catalyst (step 4). The unreacted ethanol is recovered via distillation (step 5) and recycled to the esterification reactor. Ethanol was chosen over methanol despite the higher boiling point of the ethyl lactate compared to methyl lactate due to the potential for co-location of ethanol production in the biorefineries. ${ }^{6}$ Conversions for the esterification unit (lactic acid and the byproduct acetic acid to respective esters) were calculated using a Langmuir-Hinshelwood kinetic model ${ }^{7}$ with BioSTEAM-estimated UNIFAC coefficients.

Ethyl lactate is recovered as the top product of a subsequent distillation (step 6), and the bottom product is recycled to the esterification reactor. The ester-rich stream is directed to a hydrolysis reactor, where water reacts with ethyl lactate to regenerate lactic acid and ethanol (step 7). The regenerated ethanol is then recovered via distillation and recycled to the esterification reactor (step 8). All ester-to-acid reactions of the hydrolysis unit were assumed to proceed to $80 \%$ ester conversion with a water-to-lactic acid molar ratio of $12: 1$ and a hydraulic residence time of $4 \mathrm{~h}$. After hydrolysis, the unreacted ethyl lactate is evaporated out and recycled to the hydrolysis reactor, and $88 \mathrm{wt} \%$ L-lactic acid (on weight basis) is recovered via flash as the liquid product (step 9).

Multiple technologies have been considered for the design of the separation process (Table S4), and sequential esterification-hydrolysis was selected because of (i) its feasibility and maturity in large-scale application (which excluded ion exchange chromatography, molecular distillation, and pressure-driven membrane processes), (ii) its non-interference with upstream or downstream operations (which excluded solvent extraction due to its toxicity to microbes), and (iii) its ability to consistently yield high-purity product (which excluded solvent extraction due to its low selectivity) with low maintenance requirement (which excluded pressure-driven membrane processes due to fouling issues). Although reactive distillation has been used in some lactic acid biorefineries, ${ }^{6,8,9}$ only simulation studies were found in the literature when lignocellulosic feedstocks were used, and impurities (e.g., residual sugars, other organic acids) in the fermentation broth could adversely affect the process by competing with lactic acid in esterification and hydrolysis reactions. ${ }^{10}$ Thus, separate esterification and hydrolysis reactors and distillation columns were used in this study. Electrodialysis has also been suggested as a promising technology because of its low chemical consumption, low waste generation, and its capacity of single-step separation and purification. ${ }^{10,11}$ However, it has been reported to have high energy consumption, and limited data are available at the commercial scale. ${ }^{10}$ Additionally, fouling issues have been reported when it was applied to impure, solids-laden streams (similar to the fermentation broth of lignocellulose hydrolysate), ${ }^{12,13}$ thus it was not used in this study. 


\section{S1.3. Facilities}

Solid residuals from the conversion and separation processes (solid/liquid separation steps in Figure 1, containing lignin, unconverted cellulose and hemicellulose, and fermentation microbes), biogas from anaerobic digestion, and wastewater sludge are sent to the boiler and burned to reduce waste and recover energy. Given that energy recovered from the combustion cannot generate enough steam to meet the total heating demand of the biorefinery, natural gas is purchased as a supplementary fuel ${ }^{1,14}$ to satisfy the excess energy demand. Cooling demand is managed by the cooling tower (CT) unit, which uses electricity to regenerate cooling utilities. Water usage throughout the biorefinery is managed by the process water center unit, which supplements water needs (in addition to water recycled from the reverse osmosis unit) with fresh makeup water.

To reduce total heating and cooling utility demands, a heat exchanger network is implemented. For each simulation, an initial pinch analysis is conducted to identify the pinch temperature and minimum energy targets, and viable pairs of hot and cold streams throughout the system are then matched on either side of the identified pinch. Subsequently, these matches are rigorously modeled using vapor-liquid equilibrium and simulated as process heat exchangers to calculate the offset to the utility demands of the original heat exchangers (pinch diagram in Figure S3).

\section{S1.4. Selection of Uncertainty Distributions}

To faithfully reflect the uncertainties in the parameters, a tiered system was used to determine the types and ranges of uncertainty distributions (specific distributions and references listed in Table S5):

1. For parameters with more than 20 data points (e.g., fermentation yield), we chose triangular distribution and used $5^{\text {th }}, 50^{\text {th }}$, and $95^{\text {th }}$ percentiles as the lower bound, midpoint (also baseline), and upper bound.

2. For parameters with 5-20 data points (e.g., natural gas price), we chose triangular distribution and used the minimum, average, and maximum literature value as the lower bound, midpoint (also baseline), and upper bound.

3. For parameters where the distributions were from literature and the literature suggested the range was based on experimental data (e.g., pretreatment solid loading), we chose triangular distribution and used the minimum, baseline, and maximum values from the literature distribution (or $90 \%, 100 \%$, and $110 \%$ of the baseline if minimum and maximum values were lacking) as the lower bound, midpoint (also baseline), and upper bound.

4. For parameters where the distributions were from literature, but the literature did not note the origin of the value (e.g., boiler efficiency), we used the same baseline value as the literature and chose uniform distribution with the minimum and maximum values from the literature distribution as the lower and upper bounds. 


\section{Section S2. Supplementary Figures}

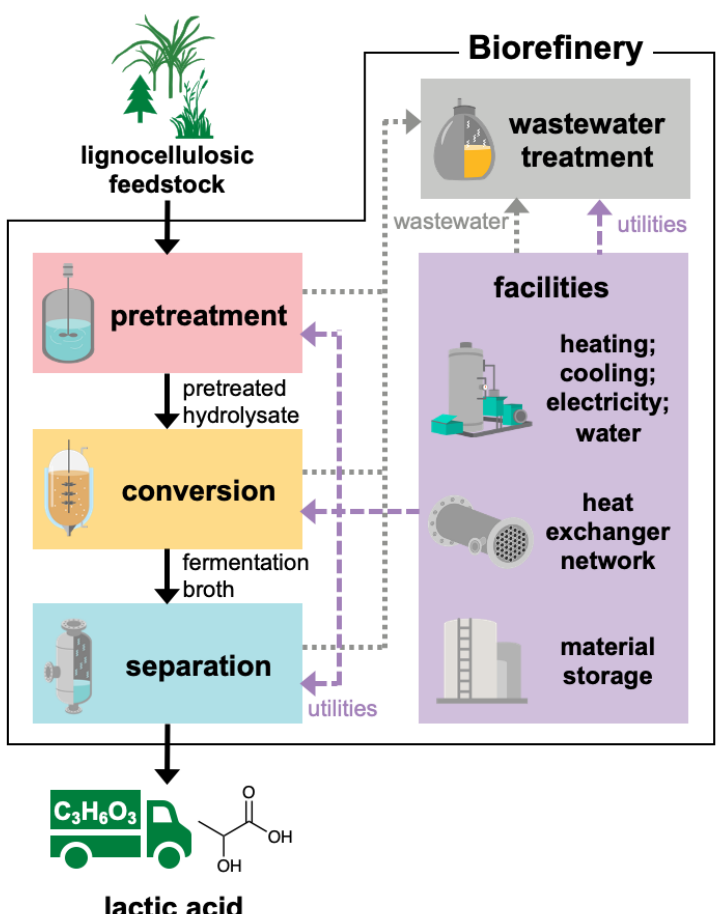

Figure S1. Overview of the biorefinery designed in this study. Pretreatment, conversion, and separation are inside-battery-limit processes; wastewater treatment and facilities are outsidebattery-limit processes. 
Titer $\left[g \cdot \mathrm{L}^{-1}\right]$

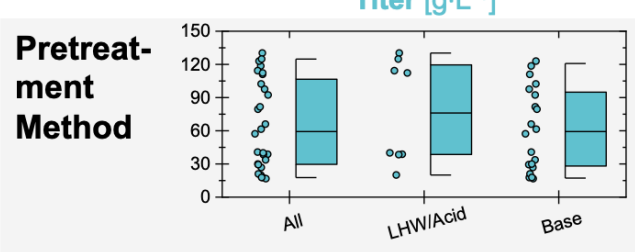

Detoxification

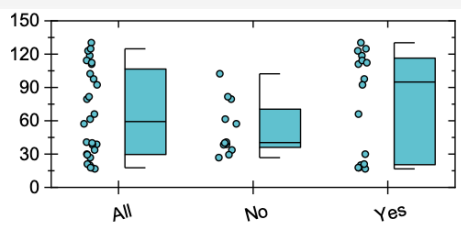

Ferm. Microbe

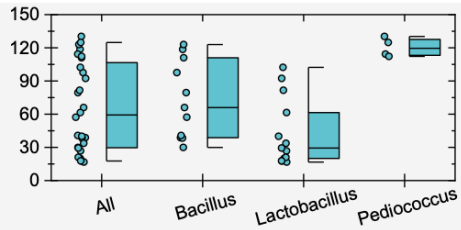

Ferm. Mode

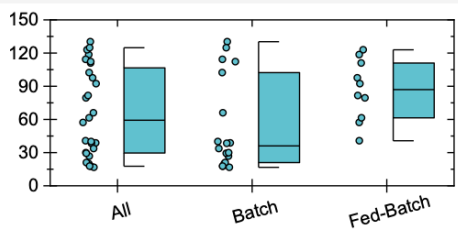

Ferm.

Neutralizer

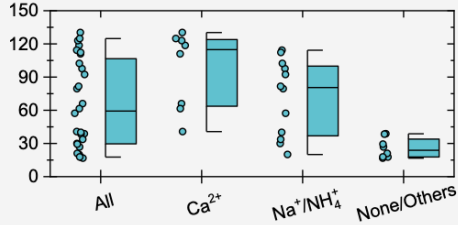

Product

Enantiomer
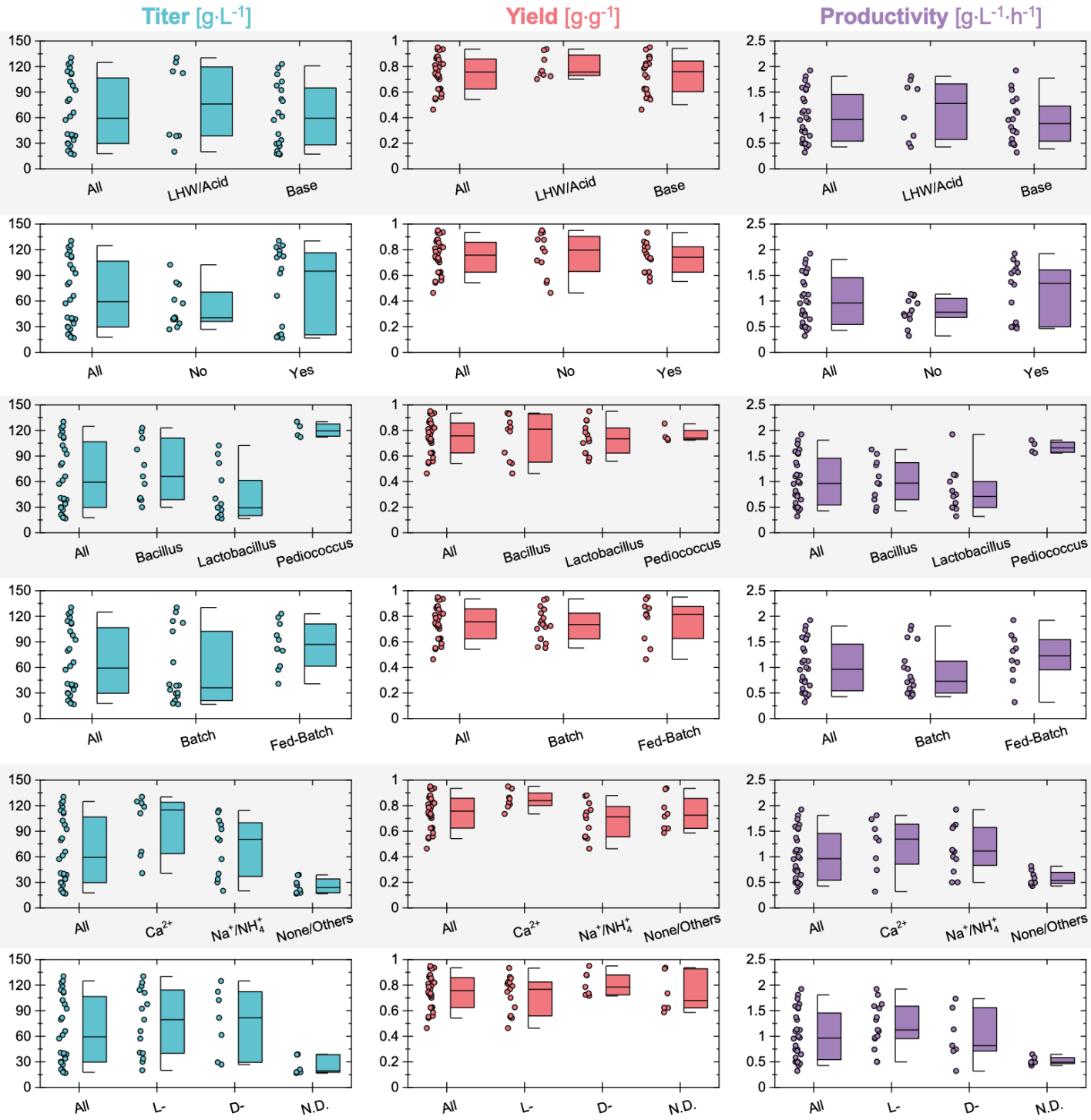

Figure S2. Comparison of lactic acid titer, productivity, and yield from fermentation of lignocellulosic biomass. For pretreatment method, LHW represents liquid hot water; for product enantiomer, N.D. represents not determined. The complete list of papers used to generate this figure is included in Table S3. 


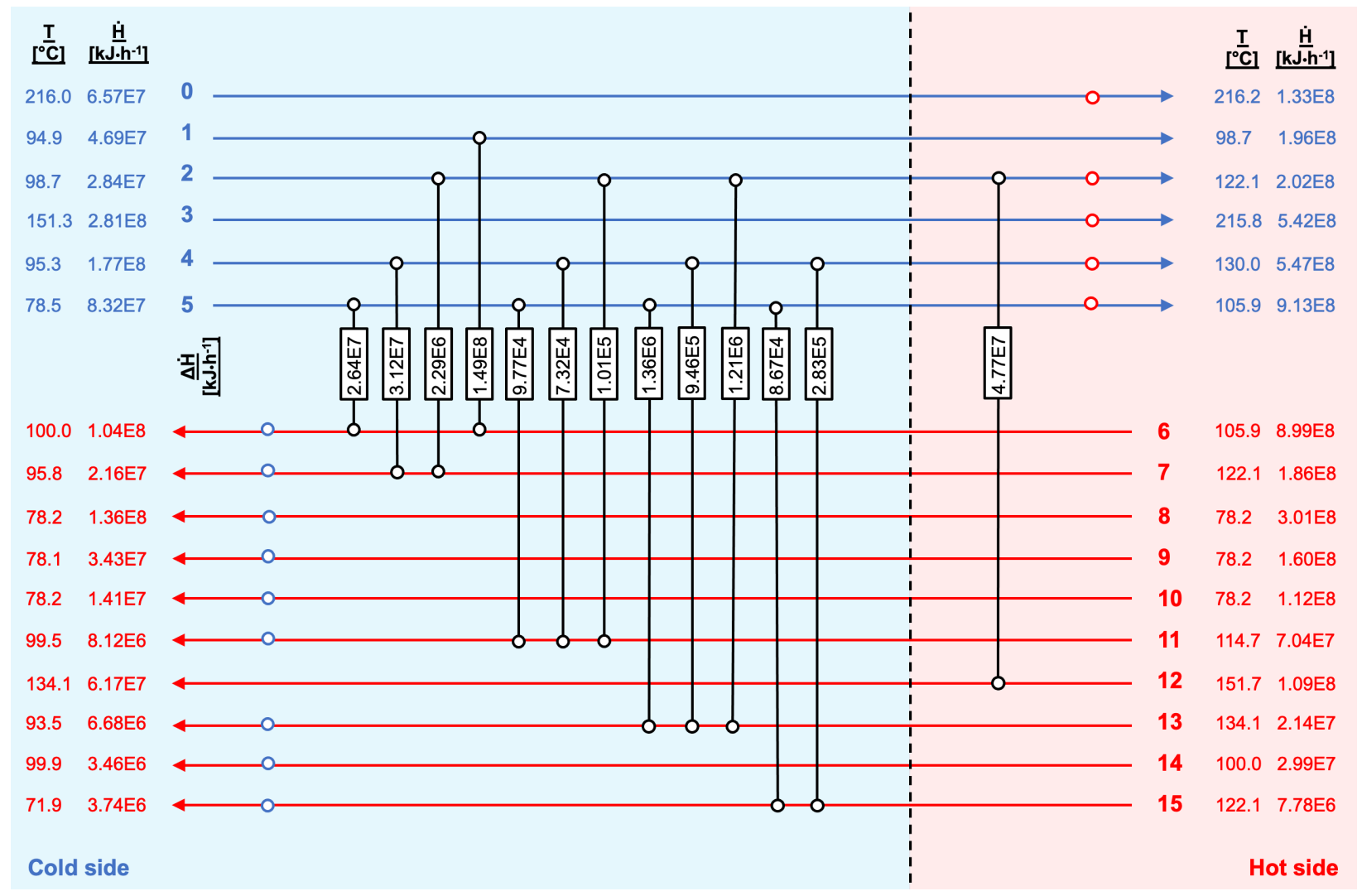

Figure S3. Pinch diagram for the heat transfers in the heat exchanger network for the baseline design. Vertical lines bound by black circles indicate heat transfer between process streams (numbers represent heat transfer, $\Delta \dot{H}$ ). Red and blue circles on horizontal lines indicate utilities used to heat and cool streams to outlet temperatures, respectively. Blue and red horizontal arrows indicate cold streams (to be heated) and hot streams (to be cooled), respectively. Stream indices are shown at the inlet (0-5 for the cold streams and 6-15 for the hot streams); temperatures (T) and heat flows $(\dot{H})$ are shown at the inlet and outlet of each stream. Units (Tables S1 and S2) associated with the streams are: (cold streams) 0: D401, 1: D404, 2: F402, 3: D403, 4: D402, and 5: F401; (hot streams) 6: F401_H, 7: F402_H1, 8: D402, 9: D404, 10: D402_H, 11: H201, 12 : D403_H, 13: D401_H, 14: D403, and 15: F402_H2. 


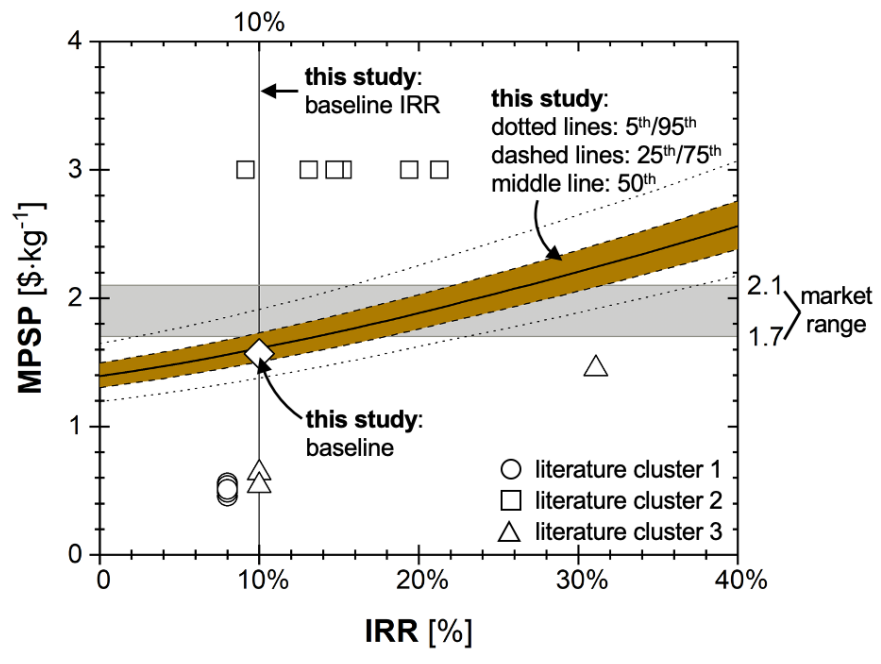

Figure S4. MPSP at different internal rates of return (IRRs) and comparison with literature. Dotted, dashed, and the middle lines represent $5^{\text {th }} / 95^{\text {th }}, 25^{\text {th }} / 75^{\text {th }}$, and $50^{\text {th }}$ percentiles from 1,000 Monte Carlo simulations; the diamond is the baseline in this study. Literature cluster 1 (circles) used dry acid pretreatment, solid state saccharification, and fermentation of glucose ${ }^{15}$ or glucose and xylose, ${ }^{16,17}$ and similar ${ }^{16,17}$ or different (ultrafiltration and electrodialysis) ${ }^{15}$ separation processes. Literature cluster 2 (squares) used steam explosion pretreatment, simultaneous saccharification and fermentation of glucose or xylose, and reactive distillation separation process. ${ }^{18}$ Literature cluster 3 (triangles) used steam explosion pretreatment, separate hydrolysis and fermentation of glucose and xylose, and reactive distillation separation process. ${ }^{8,9}$

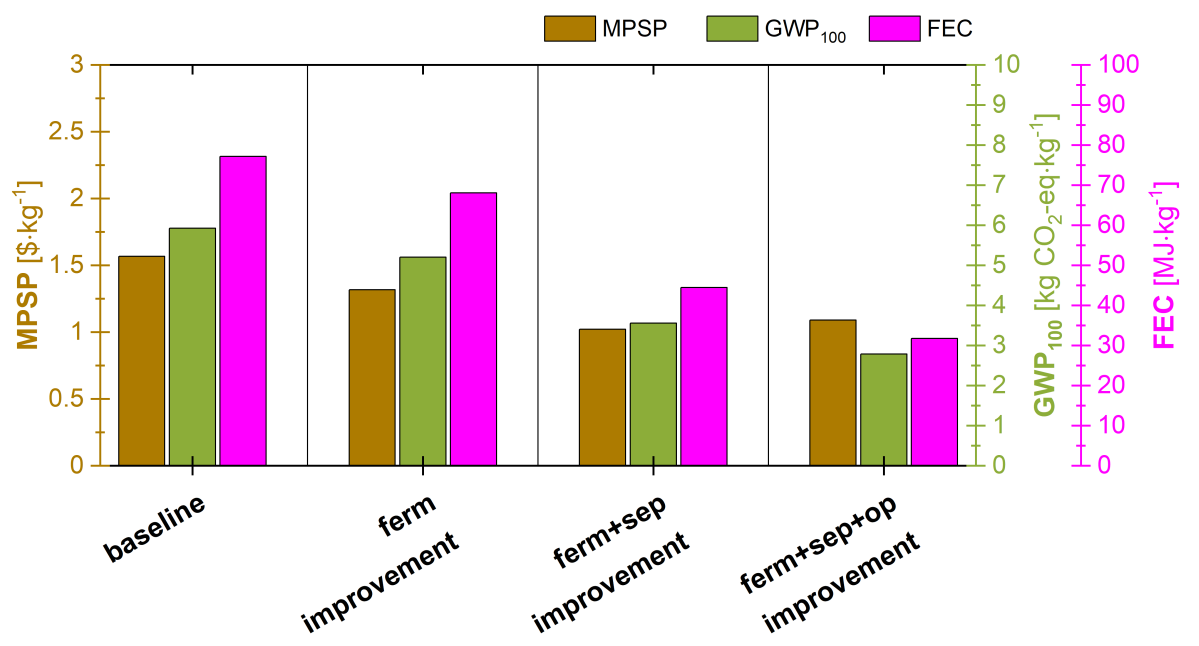

Figure S5. Changes in MPSP, GWP ${ }_{100}$, and FEC with different technological improvements and operating decisions. Fermentation (ferm) improvement: lactic acid yield increased from 0.76 to $0.95 \mathrm{~g} \cdot \mathrm{g}^{-1}$ glucose and xylose (titer increased from 97.5 to $120 \mathrm{~g} \cdot \mathrm{L}^{-1}$ accordingly), byproduct acetic acid yield decreased from 0.07 to $0 \mathrm{~g} \cdot \mathrm{g}^{-1} \mathrm{glucose}$ and xylose. Separation (sep) improvement: esterification conversion increased from $19 \%$ to $90 \%$ and hydrolysis conversion increased from $80 \%$ to $90 \%$. Operating decisions (op): purchasing $25 \%$ of natural gas from renewable sources and diverting $25 \%$ of feedstock directly to the boiler. 
A

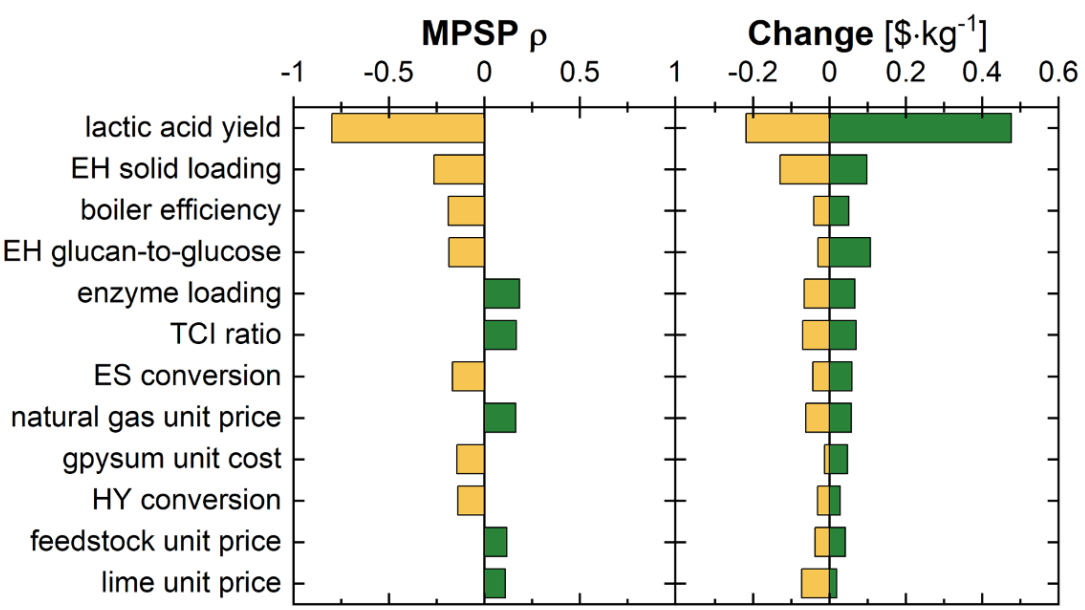

B

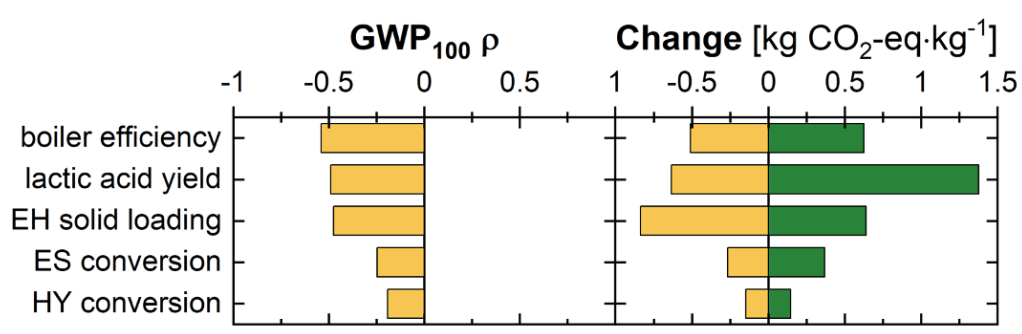

C

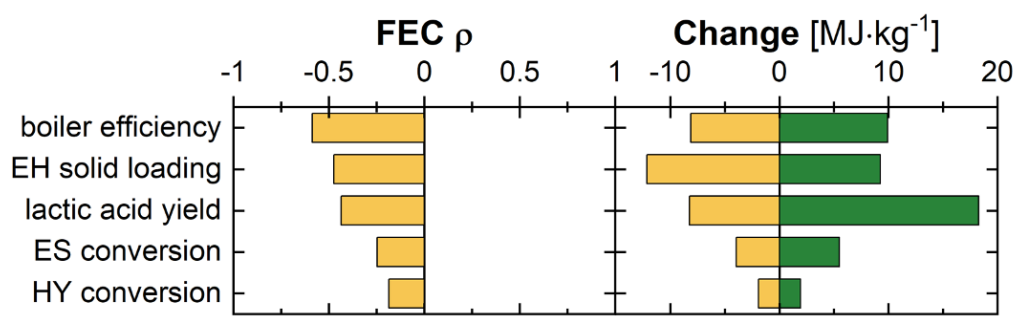

Figure S6. (Left panel) Spearman's $\rho$ values for input parameters and MPSP, GWP ${ }_{100}$, and FEC, and (right panel) changes in these sustainability indicators when shifting the baseline assumption to the minimum or maximum value of each individual parameter. The absolute value of Spearman's $\rho$ represents strength of the rank order correlation and the symbol (+ or -) represents positive or negative correlation. EH represents enzymatic hydrolysis (i.e., saccharification), EH solid loading represents the solid concentration during $\mathrm{EH}$, enzyme loading represents the amount of enzyme added per gram of cellulose during $\mathrm{EH}$. TCl ratio represents total capital investment as \% of the value simulated by BioSTEAM, ES represents esterification, and $\mathrm{HY}$ represents hydrolysis. Only parameters with absolute values of $\rho \geq 0.1$ are included in this figure. The full list of evaluated parameters, their distributions, and their $\rho$ values for all three indicators can be found in Table S5. 


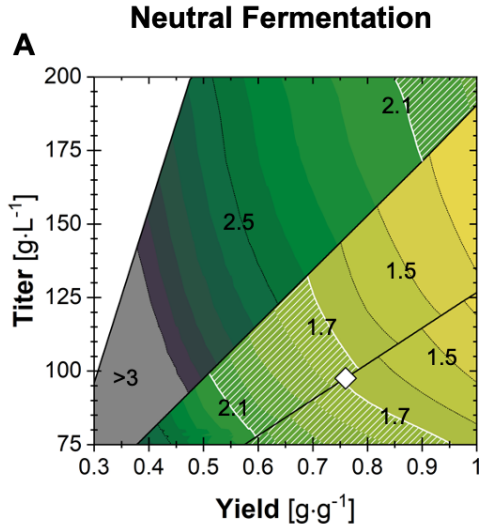

C

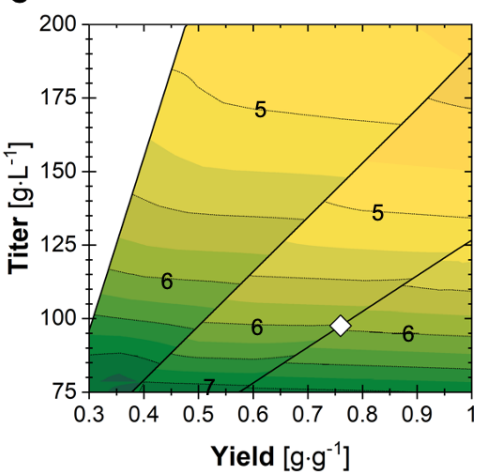

E

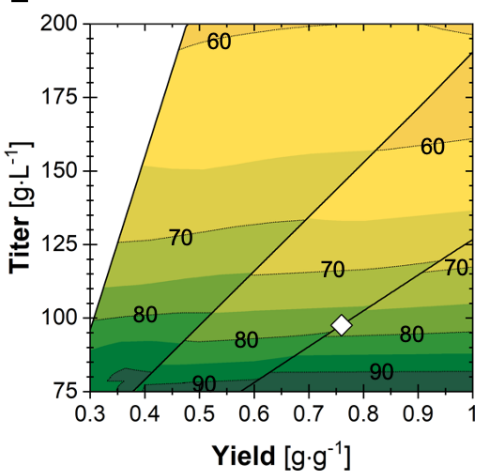

Low-pH Fermentation
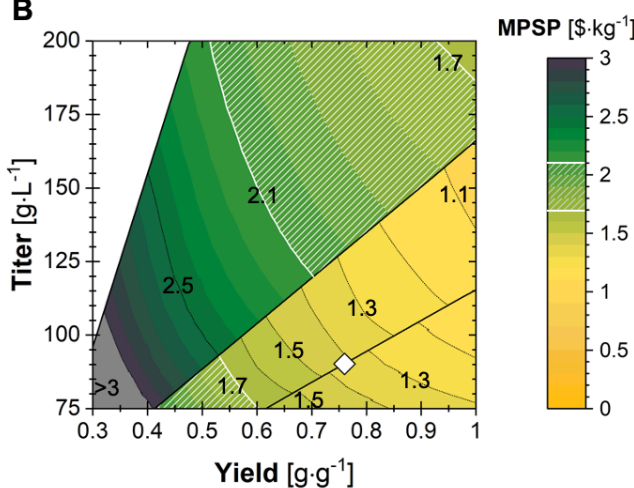

D

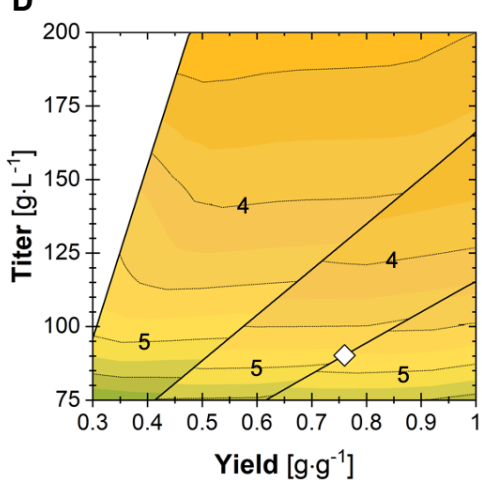
$\left[\mathrm{kg} \mathrm{CO}-\mathrm{eq} \cdot \mathrm{kg}^{-1}\right]$

$\mathbf{F}$

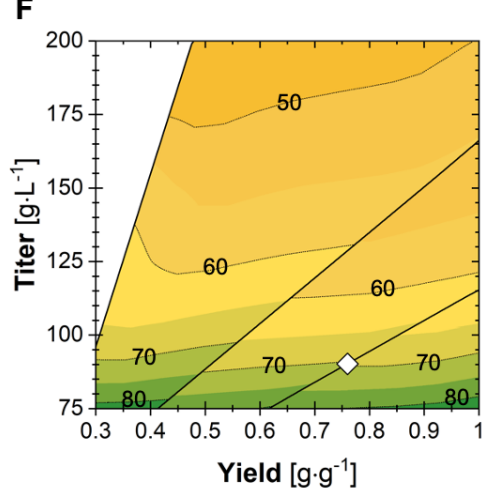

GWP $_{100}$
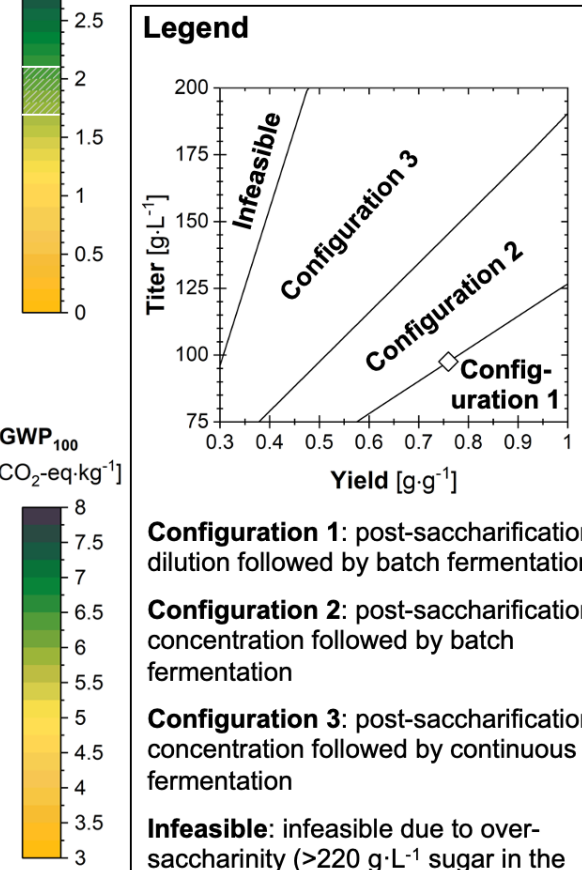

Configuration 1: post-saccharification dilution followed by batch fermentation

Configuration 2: post-saccharification concentration followed by batch fermentation

Configuration 3: post-saccharification concentration followed by continuous fermentation

Infeasible: infeasible due to oversaccharinity $\left(>220 \mathrm{~g}^{\cdot \mathrm{L}^{-1}}\right.$ sugar in the saccharified stream)

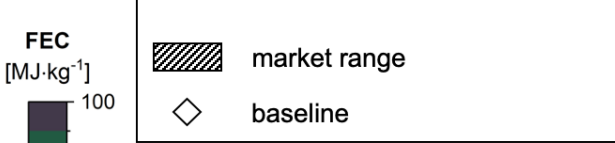

Figure S7. (A, B) MPSP, (C, D) GWP 100 , and (E, F) FEC across the spectrum of titer and yield combinations at a productivity of $0.18 \mathrm{~g} \cdot \mathrm{L}^{-1} \cdot \mathrm{h}^{-1}$ (the minimum productivity from collected data, Table S3) for neutral (left panel; A, C, E) and low-pH (right panel; B, D, F) fermentation. For a given point on the figure, the $x$-axis value represents the yield (same for glucose and xylose), the $y$-axis value represents the titer, and the color represents the value of MPSP, GWP ${ }_{100}$, or FEC (values at the same titer-yield combination are from the same simulation). Three different configurations (Configurations 1-3, legend) were designed to simulate all potential titer-yield combinations (Figure 1A; details in Section S2.1). 

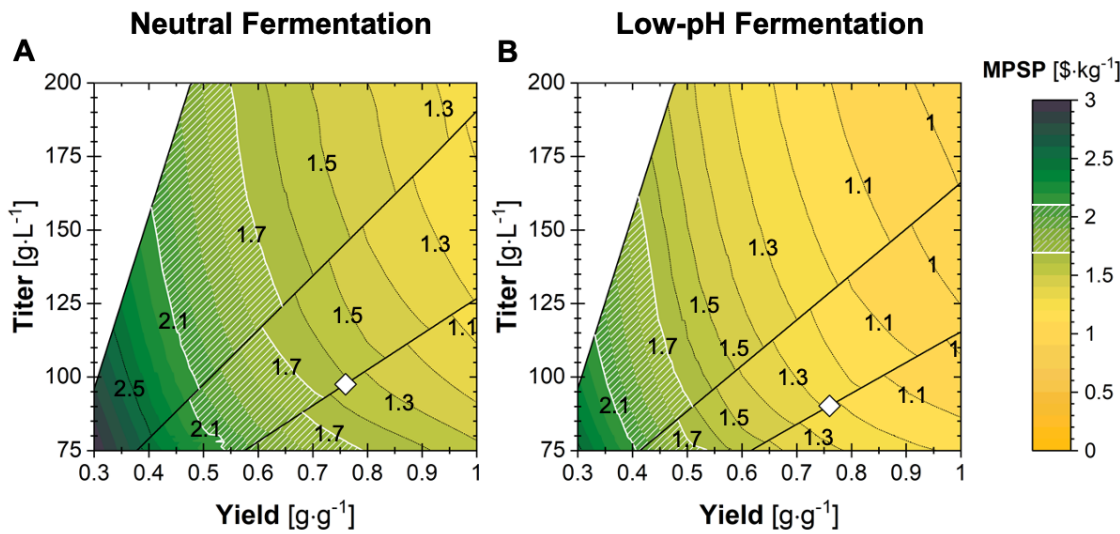

C

D
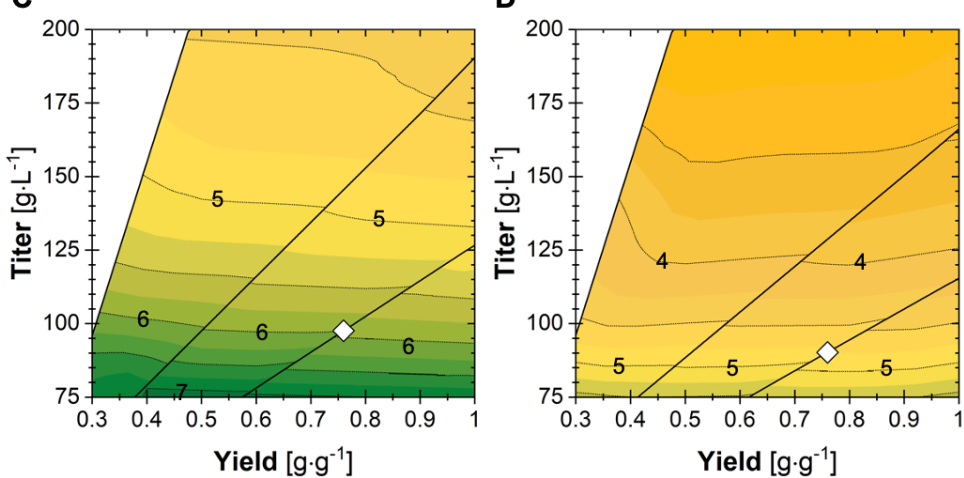

GWP $_{100}$ $\left[\mathrm{kg} \mathrm{CO}_{2}\right.$-eq $\left.\cdot \mathrm{kg}^{-1}\right]$
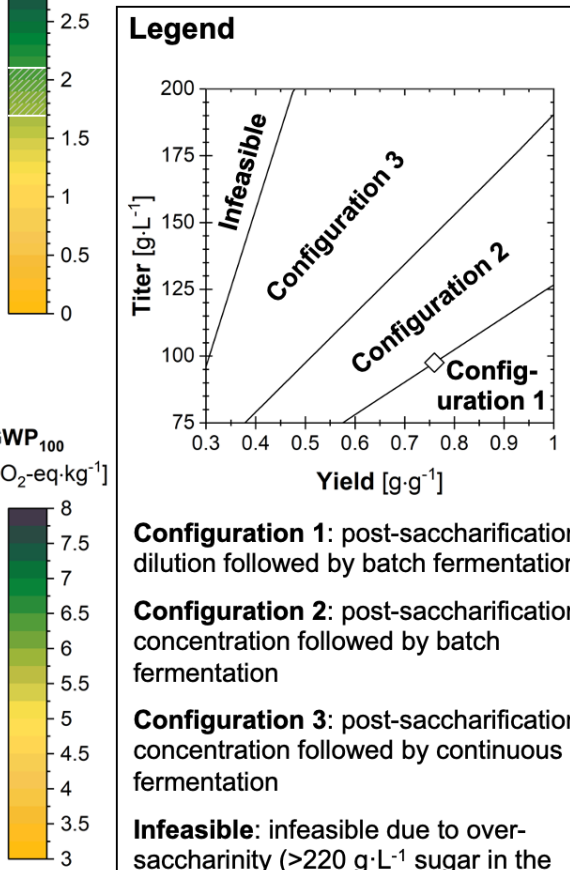

Configuration 1: post-saccharification dilution followed by batch fermentation

Configuration 2: post-saccharification concentration followed by batch fermentation

Configuration 3: post-saccharification concentration followed by continuous fermentation

Infeasible: infeasible due to oversaccharinity (>220 g. $\mathrm{L}^{-1}$ sugar in the saccharified stream)

E

$\mathbf{F}$
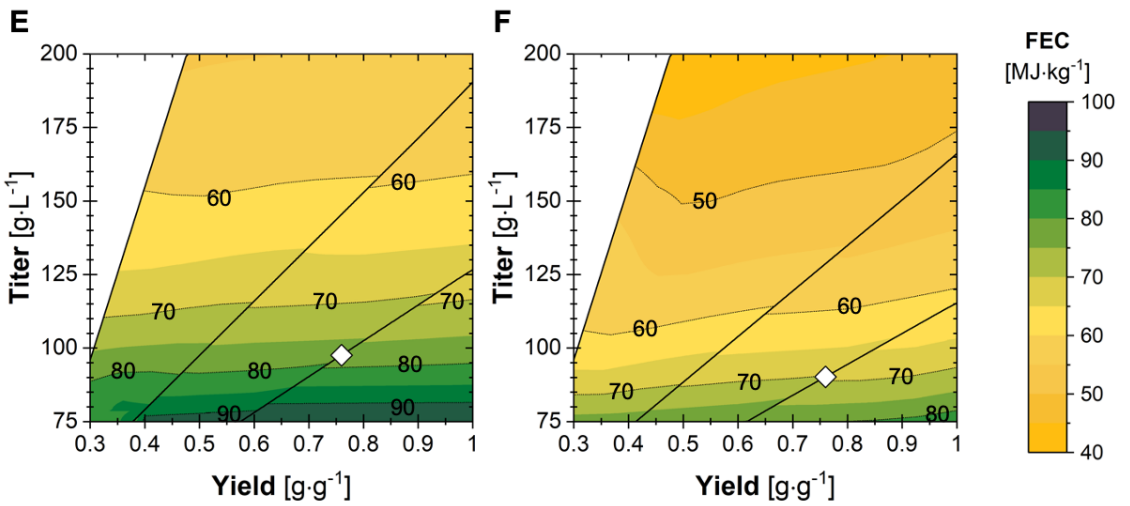

Figure S8. (A, B) MPSP, (C, D) GWP 100 , and (E, F) FEC across the spectrum of titer and yield combinations at a productivity of $1.92 \mathrm{~g} \cdot \mathrm{L}^{-1} \cdot \mathrm{h}^{-1}$ (the maximum productivity from collected data, Table S3) for neutral (left panel; A, C, E) and low-pH (right panel; B, D, F) fermentation. For a given point on the figure, the $x$-axis value represents the yield (same for glucose and xylose), the $y$-axis value represents the titer, and the color represents the value of MPSP, GWP ${ }_{100}$, or FEC (values at the same titer-yield combination are from the same simulation). Three different configurations (Configurations 1-3, legend) were designed to simulate all potential titer-yield combinations (Figure 1A; details in Section S2.1). 


\section{Section S3. Supplementary Tables}

Table S1. List of major units and equipment included in the biorefinery (refer to Table S2 for units in the separation process).

\begin{tabular}{|c|c|c|c|c|}
\hline Process & ID & Unit & Equipment & Source \\
\hline \multirow{4}{*}{ preprocessing $^{\mathrm{a}}$} & \multirow{4}{*}{ U101 } & \multirow{4}{*}{ feedstock preprocessing } & truck scale, dumper, dumper hopper & \multirow{4}{*}{5} \\
\hline & & & dust collection system & \\
\hline & & & feedstock storage dome, reclaim system & \\
\hline & & & conveyor & \\
\hline \multirow{12}{*}{ pretreatment } & T201 & sulfuric acid addition & tank, pump & 5 \\
\hline & M201 & sulfuric acid mixing & in-line mixer & 5 \\
\hline & \multirow{3}{*}{ R201 } & \multirow{3}{*}{ pretreatment } & storage bin, conveyor, feeder, preheater & 5 \\
\hline & & & $\begin{array}{c}\text { pressurized heating screw, transport, } \\
\text { discharge }\end{array}$ & \multirow[t]{2}{*}{5} \\
\hline & & & reactor & \\
\hline & T202 & blowdown & tank, agitator, pump & 5 \\
\hline & T203 & oligomer conversion & tank, agitator, pump & 5 \\
\hline & F201 & flash & tank, agitator, pump & 5 \\
\hline & $\mathrm{H} 201$ & waste vapor condensation & condenser & 5 \\
\hline & M205 & ammonia mixing & mixer & 5 \\
\hline & T204 & ammonia addition & tank, agitator & 5 \\
\hline & P201 & hydrolysate pumping & pump & 5 \\
\hline \multirow{5}{*}{ fermentation } & M301 & enzyme mixing & in-line mixer & 5 \\
\hline & \multirow{2}{*}{$\mathrm{R} 301^{\mathrm{b}}$} & \multirow{2}{*}{$\begin{array}{l}\text { saccharification and co- } \\
\text { fermentation }\end{array}$} & enzymatic hydrolysis tank, pump & \multirow{2}{*}{$\begin{array}{c}\text { design based on }{ }^{5} \\
\text { and Table } S 3, \text { costs } \\
\text { based on } 5\end{array}$} \\
\hline & & & fermenter, agitator, pump & \\
\hline & R302 & seed train & seed fermenter, agitator, pump & $\begin{array}{c}\text { design based on }{ }^{5} \\
\text { and Table S3, costs } \\
\text { based on } 5\end{array}$ \\
\hline & T301 & seed holding & tank, agitator, pump & 5 \\
\hline \multirow{6}{*}{$\begin{array}{l}\text { waste } \\
\text { treatment }\end{array}$} & R501 & anaerobic digestion & anaerobic basin & 1 \\
\hline & R502 & aerobic digestion & caustic feed, aerobic basin & 1 \\
\hline & S501 & membrane bioreactor & reactor, conveyor & 1 \\
\hline & S503 & sludge thickening & belt thickener & 1 \\
\hline & S504 & sludge centrifuge & centrifuge & 1 \\
\hline & S505 & reverse osmosis (RO) & reactor, evaporator & 1 \\
\hline
\end{tabular}

a Capital and operating costs of the preprocessing process are zero as they are included in the cost of feedstock.

b To concentrate the sugar-rich stream after saccharification (Configurations 2 and 3 in Figure 4 and Figures S7 and S8), a multi-effect evaporator (E301, design and cost based on BioSTEAM) was added prior to R301, and R301 was separated into a saccharification (R300) unit and a co-fermentation (R301) unit. When batch fermentation was used (Configurations 1 and 2 in Figure 4, S7, and S8), the design of R301 was based on Humbird et al. ${ }^{5}$ and Table S3, and equipment costs of R301 were based on Humbird et al.; when continuous fermentation was used (Configuration 3 in Figure 4, S7, and S8), the design of R301 was based on BioSTEAM design algorithms and Table S3, and equipment costs of R301 were based on BioSTEAM. 
Table S1 (Continued). List of major units and equipment included in the biorefinery (refer to Table S2 for units in the separation process).

\begin{tabular}{|c|c|c|c|c|}
\hline Process & ID & Unit & Equipment & Source \\
\hline \multirow{25}{*}{ facilities } & T601 & lactic acid storage & tank & BioSTEAM \\
\hline & T601_P & pumping & pump & BioSTEAM \\
\hline & T602 & sulfuric acid storage & tank, pump & 5 \\
\hline & T603 & ammonia storage & tank & 5 \\
\hline & T604 & CSL storage & tank, agitator, pump & 5 \\
\hline & T605 & lime storage & storage bin, feeder, blower, baghouse & 19 \\
\hline & T606 & ethanol storage & tank & BioSTEAM \\
\hline & T606_P & pumping & pump & BioSTEAM \\
\hline & T607 & fire water storage & tank, pump & 5 \\
\hline & \multirow{12}{*}{$\mathrm{CHP}^{\mathrm{a}}$} & \multirow{12}{*}{ boiler } & boiler & \multirow{12}{*}{1} \\
\hline & & & boiler air intake fan, preheater & \\
\hline & & & boiler combustion gas baghouse & \\
\hline & & & boiler feed water preheater, pump & \\
\hline & & & boiler blowdown flash, pump & \\
\hline & & & turbogenerator, pump & \\
\hline & & & $\begin{array}{c}\text { turbogenerator condensate tank, pump, } \\
\text { surge drum }\end{array}$ & \\
\hline & & & water softener system & \\
\hline & & & deaerator, pump & \\
\hline & & & amine addition package, drum, pump & \\
\hline & & & ammonia addition package & \\
\hline & & & phosphate addition package & \\
\hline & CT & cooling tower & cooling tower system, pump & 5 \\
\hline & PWC & process water center & tank, pump & 5 \\
\hline & ADP & air distribution package & air compressor, receiver, dryer & 5 \\
\hline & CIP & clean-in-place & CIP system & 5 \\
\hline
\end{tabular}

a The boiler is modeled based on the combined heat and power (CHP) unit in the reference, ${ }^{1}$ where the surplus energy (embedded energy in residual biomass minus plant heating demand) is used for electricity production. However, in all simulations performed for this study, the energy recovered from residual biomass was not sufficient to meet the plant's heating demand and no electricity was produced. Therefore, the capital and operating costs associated with turbogenerator were set to zero and the unit was referred to as "boiler" in the main text to avoid confusion. 
Table S2. List of major units and equipment included in the separation process.

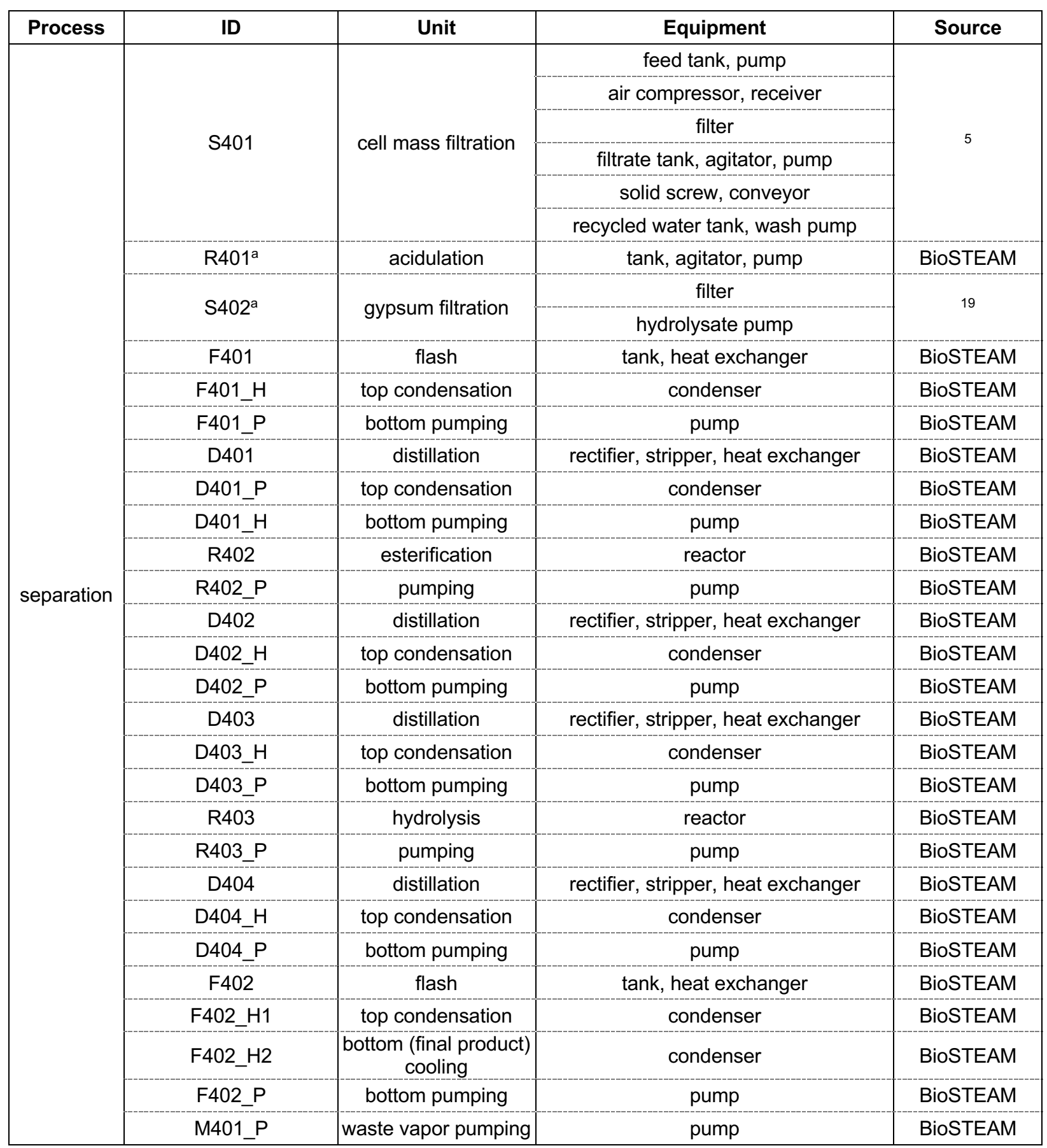

${ }^{a}$ Bypassed in low-pH fermentation scenario (fermentation does not require lime addition; thus, there is no need for acidulation and gypsum removal). 
Table S3. Reference literature for design of saccharification and fermentation units.

\begin{tabular}{|c|c|c|c|c|c|c|c|c|c|c|c|c|}
\hline \multirow{3}{*}{$\begin{array}{c}\begin{array}{c}\text { Pretreatment } \\
\text { Method }\end{array} \\
\mathrm{NH}_{4} \mathrm{OH} \\
\end{array}$} & \multirow{3}{*}{$\begin{array}{c}\begin{array}{c}\text { Detoxification } \\
\text { Method }\end{array} \\
\text { None }\end{array}$} & \multicolumn{2}{|c|}{ Prehydrolysis } & \multicolumn{5}{|c|}{ Fermentation } & \multicolumn{3}{|c|}{ Product Analysis } & \multirow{2}{*}{ Ref } \\
\hline & & $\mathrm{t}$ [h] & $\mathrm{T}\left[{ }^{\circ} \mathrm{C}\right]$ & Microbe & Mode & $t[h]$ & $\mathrm{T}\left[{ }^{\circ} \mathrm{C}\right]$ & pH control & \multicolumn{2}{|c|}{ Lactic Acid $^{\mathrm{a}}$} & \multirow{2}{*}{$\begin{array}{c}{\text { Acetic } \text { Acid }^{\mathbf{b}}}^{0} \\
0.01\end{array}$} & \\
\hline & & - & - & Bacillus & Fed-batch & 48 & 50 & 6 by $\mathrm{NaOH}$ & 79.5 & $0.54 \quad 1.10$ & & \multirow{3}{*}{20} \\
\hline $\mathrm{NH}_{4} \mathrm{OH}$ & Water washing & - & - & Bacillus & Fed-batch & 48 & 50 & 6 by $\mathrm{CaCO}_{3}$ & 118.6 & $0.93 \quad 1.32$ & 0.004 & \\
\hline $\mathrm{NaOH}$ & Water washing & - & - & Bacillus & Fed-batch & 48 & 50 & 6 by $\mathrm{CaCO}_{3}$ & L- 123.0 & $\begin{array}{lll}0.86 & 1.37\end{array}$ & 0.004 & \\
\hline $\mathrm{H}_{2} \mathrm{SO}_{4}$ & None & 15 & 52 & Bacillus & Batch & 45 & 50 & 5 & N.D. 38.7 & 0.940 .65 & - & \multirow[t]{2}{*}{21} \\
\hline $\mathrm{H}_{2} \mathrm{SO}_{4}$ & None & 26 & 52 & Bacillus & Batch & 64 & 50 & 5 & N.D. 38.4 & $0.93 \quad 0.43$ & - & \\
\hline Lime & None & 13 & 50 & Bacillus & Batch & 42 & 50 & 6 by $\mathrm{Ca}(\mathrm{OH})_{2}$ & \begin{tabular}{|ll} 
L- & 40.7 \\
\end{tabular} & 0.810 .74 & - & 22 \\
\hline $\mathrm{NaOH}$ & Water washing & - & - & Bacillus & Batch & 60 & 50 & 6 by $\mathrm{NaOH}$ & 29.9 & 0.550 .50 & 0.08 & \multirow{3}{*}{23} \\
\hline $\mathrm{NaOH}$ & None & - & - & Bacillus & Fed-batch & 60 & 50 & 6 by $\mathrm{NaOH}$ & 57.3 & $\begin{array}{lll}0.46 & 0.95\end{array}$ & 0.21 & \\
\hline $\mathrm{NaOH}$ & Water washing & - & - & Bacillus & Fed-batch & 60 & 50 & 6 by $\mathrm{NaOH}$ & 97.6 & 0.631 .63 & 0.07 & \\
\hline $\mathrm{NaOH}$ & Water washing & - & - & Bacillus & Batch & 68 & 50 & 5.6 by $\mathrm{Ca}(\mathrm{OH})_{2}$ & 66.0 & $\begin{array}{lll}0.82 & 0.97\end{array}$ & 0.05 & \multirow[t]{2}{*}{24} \\
\hline $\mathrm{NaOH}$ & Water washing & - & - & Bacillus & Fed-batch & 72 & 50 & $5.2-6.2$ by $\mathrm{Ca}(\mathrm{OH})_{2}$ & 111.0 & 0.791 .54 & 0.06 & \\
\hline LHW & None & 72 & 50 & Lactobacillus & Batch & 40 & 37 & $5.2-6.2$ by $\mathrm{Ca}(\mathrm{OH})_{2}$ & 40.0 & $\begin{array}{ll}0.70 & 0.36 \\
\end{array}$ & - & \multirow{2}{*}{25} \\
\hline LHW & Water washing & 72 & 50 & Lactobacillus & Batch & 40 & 37 & 6 by $\mathrm{NH}_{4} \mathrm{OH}$ & 20.0 & $0.77 \quad 0.18$ & 0.04 & \\
\hline $\mathrm{NaOH}$ & None & - & - & Lactobacillus & Batch & 30 & 37 & 6 by $\mathrm{NaOH}$ & 33.7 & $0.56 \quad 1.12$ & 0.47 & \multirow{2}{*}{26} \\
\hline $\mathrm{NaOH}$ & Water washing & - & - & Lactobacillus & Fed-batch & 48 & 37 & 6 by $\mathrm{NaOH}$ & 92.3 & $0.82 \quad 1.92$ & 0.30 & \\
\hline $\mathrm{NaOH}$ & None & - & - & Lactobacillus & Batch & 36 & 37 & 5 by sodium citrate & 26.8 & $0.72 \quad 0.74$ & 0.17 & \multirow{3}{*}{27} \\
\hline $\mathrm{NaOH}$ & None & - & - & Lactobacillus & Batch & 36 & 37 & 5 by sodium citrate & 29.4 & $\begin{array}{ll}0.78 & 0.82\end{array}$ & 0.14 & \\
\hline $\mathrm{NaOH}$ & None & - & - & Lactobacillus & Fed-batch & 192 & 37 & $30 \mathrm{~g} \cdot \mathrm{L}^{-1} \mathrm{CaCO}_{3}$ & 61.4 & $\begin{array}{lll}0.95 & 0.32\end{array}$ & 0.19 & \\
\hline $\mathrm{NaOH}$ & None & 3 & 50 & Lactobacillus & Fed-batch & 72 & 37 & 5.5 by $\mathrm{NaOH}$ & 81.6 & $0.88 \quad 1.09$ & - & \multirow[t]{2}{*}{28} \\
\hline $\mathrm{NaOH}$ & None & - & - & Lactobacillus & Batch & 144 & 37 & 6 by $\mathrm{NaOH}$ & D- 102.3 & $0.88 \quad 0.71$ & - & \\
\hline $\mathrm{NaOH}$ & Water washing & - & - & Lactobacillus & Batch & 36 & 37 & By feedstock ${ }^{c}$ & N.D. 17.7 & 0.620 .49 & 0.03 & \multirow{4}{*}{29} \\
\hline $\mathrm{NaOH}$ & Water washing & - & - & Lactobacillus & Batch & 36 & 37 & By feedstock & N.D. 16.7 & $\begin{array}{lll}0.59 & 0.46\end{array}$ & 0.11 & \\
\hline $\mathrm{NaOH}$ & Water washing & - & - & Lactobacillus & Batch & 36 & 37 & By feedstock & N.D. 21.0 & $\begin{array}{lll}0.74 & 0.58\end{array}$ & 0.07 & \\
\hline $\mathrm{NaOH}$ & Water washing & - & - & Lactobacillus & Batch & 36 & 37 & By feedstock ${ }^{c}$ & N.D. 17.8 & 0.620 .49 & 0.04 & \\
\hline $\mathrm{H}_{2} \mathrm{SO}_{4}$ & Biodetoxification & 6 & 50 & Pediococcus & Batch & 72 & 42 & 5.5 by $\mathrm{NaOH}$ & L- 114.3 & $0.75 \quad 1.47$ & - & \multirow{4}{*}{17} \\
\hline $\mathrm{H}_{2} \mathrm{SO}_{4}$ & Biodetoxification & 6 & 50 & Pediococcus & Batch & 72 & 42 & 5.5 by $\mathrm{Ca}(\mathrm{OH})_{2}$ & 130.3 & $\begin{array}{ll}0.85 & 1.67\end{array}$ & - & \\
\hline $\mathrm{H}_{2} \mathrm{SO}_{4}$ & Biodetoxification & 6 & 50 & Pediococcus & Batch & 72 & 42 & 5.5 by $\mathrm{NaOH}$ & 112.2 & $0.72 \quad 1.44$ & - & \\
\hline $\mathrm{H}_{2} \mathrm{SO}_{4}$ & Biodetoxification & 6 & 50 & Pediococcus & Batch & 72 & 42 & 5.5 by $\mathrm{Ca}(\mathrm{OH})_{2}$ & D- 124.8 & $0.74 \quad 1.60$ & - & \\
\hline
\end{tabular}

${ }^{a}$ Columns are (left to right) enantiomer (N.D. denotes not determined), final titer $\left(g \cdot \mathrm{L}^{-1}\right)$, final yield $\left(\mathrm{g} \cdot \mathrm{g}-\mathrm{sugar}^{-1}\right)$, and average productivity $\left(\mathrm{g} \cdot \mathrm{L}^{-1} \cdot \mathrm{h}^{-1}\right)$ of lactic acid.

${ }^{\mathrm{b}}$ Final yield of acetic acid $\left(\mathrm{g} \cdot \mathrm{g}\right.$-sugar $\left.{ }^{-1}\right)$. Yields of other byproducts (including ethanol and succinic acid) were minor in all studies that reported those data.

${ }^{c}$ Feedstock was pretreated by $\mathrm{NaOH}$ which subsequently neutralized the produced acids. 
Table S4. Considerations for the choice of separation process in the biorefinery design.

\begin{tabular}{|c|c|c|c|c|}
\hline Process & Advantage(s) & Ref & Disadvantage(s) & Ref \\
\hline $\begin{array}{l}\text { sequential } \\
\text { esterification-hydrolysis } \\
\text { (chosen in this study) }\end{array}$ & $\begin{array}{l}\text { Mature technology with commercial application for lactic } \\
\text { acid production. }\end{array}$ & 6,30 & $\begin{array}{l}\text { With sequential reactors, a cumbersome number of units } \\
\text { are needed. }\end{array}$ & 31 \\
\hline \multirow[t]{2}{*}{ solvent extraction } & Less waste generation. & 11 & $\begin{array}{l}\text { Solvents that are currently studied for lactic acid } \\
\text { extraction have low partition coefficients and selectivity, } \\
\text { thus necessitating high exchange area and solvent } \\
\text { recovery cost. }\end{array}$ & $10,11,31$ \\
\hline & $\begin{array}{l}\text { Promising results from novel solvents on the laboratory } \\
\text { scale. }\end{array}$ & 11 & $\begin{array}{l}\text { Due to low partition coefficient, recycling of raffinate is } \\
\text { necessary, which is toxic to fermentation microbes. }\end{array}$ & 10,11 \\
\hline \multirow{3}{*}{ electrodialysis } & Low environmental impact. & 10 & High energy consumption. & 10 \\
\hline & Potentially easy to scale up. & 10 & \multirow{2}{*}{ Lack of data for commercial production. } & \multirow{2}{*}{10} \\
\hline & Single-step separation and purification. & 10 & & \\
\hline \multirow{3}{*}{$\begin{array}{l}\text { pressure-driven } \\
\text { membrane processes }\end{array}$} & $\begin{array}{l}\text { Potential for high selectivity with respect to other broth } \\
\text { components. }\end{array}$ & 10,11 & High capital cost of membranes. & 10,11 \\
\hline & $\begin{array}{l}\text { Potential for high-purity product without further } \\
\text { purification. }\end{array}$ & 11 & High cost of replacing fouled membranes. & 10,11 \\
\hline & Low waste generation. & 31 & Scale-up is difficult. & 11 \\
\hline \multirow{2}{*}{$\begin{array}{l}\text { molecular distillation / } \\
\text { short-path evaporation }\end{array}$} & Reduced risk of thermal decomposition. & 10,11 & Difficult to scale up. & 10,11 \\
\hline & High-purity product without further purification. & 10,11 & Requires high vacuum conditions. & 10,11 \\
\hline \multirow{4}{*}{$\begin{array}{l}\text { ion exchange } \\
\text { chromatography }\end{array}$} & High selectivity with respect to other broth components. & 10 & Difficult to scale up. & 10 \\
\hline & Low energy consumption. & 10 & Significant fraction of lactic acid is retained in the broth. & 10 \\
\hline & Low material usage. & 10 & Regeneration of resin generates waste streams. & 10 \\
\hline & Low product loss. & 31 & $\begin{array}{l}\text { High heat utility requirements due to high number of } \\
\text { distillation steps. }\end{array}$ & 31 \\
\hline
\end{tabular}


Table S5. List of parameters included in the uncertainty analysis. ${ }^{a}$

\begin{tabular}{|c|c|c|c|c|c|c|c|}
\hline \multirow[b]{2}{*}{ Parameter } & \multirow[b]{2}{*}{ Unit } & \multirow[b]{2}{*}{ Baseline } & \multirow[b]{2}{*}{ Distributions } & \multirow[b]{2}{*}{ References } & \multicolumn{3}{|c|}{ Spearman's $\rho$} \\
\hline & & & & & MPSP & GWP $_{100}$ & FEC \\
\hline \multicolumn{8}{|l|}{ TEA } \\
\hline plant uptime & $\%$ of year & $90 \%$ & $\begin{array}{l}84 \%, 90 \%, 96 \% \\
\text { triangular }\end{array}$ & $\begin{array}{c}\text { baseline and upper bound from }{ }^{1} \text {, lower bound } \\
\text { set to be equal difference from baseline as the } \\
\text { upper bound }\end{array}$ & -0.07 & 0.01 & 0.01 \\
\hline total capital investment & $\%$ of simulated value & $100 \%$ & $\begin{array}{l}\text { simulated value } \pm 25 \% \\
\text { triangular }\end{array}$ & $\begin{array}{l}\text { simulated by BioSTEAM (references noted in } \\
\text { scripts), range consistent with } 1\end{array}$ & 0.17 & -0.02 & -0.02 \\
\hline feedstock price & $\$ \cdot$ dry-ton $^{-1}$ & 71.3 & $60,71.3,83.7$, triangular & $\begin{array}{c}\text { baseline and lower bound from }{ }^{1} \text {, upper bound } \\
\text { from } 32\end{array}$ & 0.11 & -0.01 & -0.01 \\
\hline sulfuric acid price & $\$ \cdot \mathrm{kg}^{-1}$ & 0.0948 & $\begin{array}{c}0.0910,0.0948,0.1046 \\
\text { triangular }\end{array}$ & $\begin{array}{c}\text { baseline from }{ }^{1} \text {, range is the minimum and } \\
\text { maximum values calculated using price index } \\
\text { of sulfuric acid from } 2015-2019 \text { from U.S. } \\
\text { Bureau of Labor Statistics }\end{array}$ & 0.01 & -0.05 & -0.05 \\
\hline lime price & $\$ \cdot \mathrm{kg}^{-1}$ & 0.262 & $\begin{array}{l}0.160,0.262,0.288 \\
\text { triangular }\end{array}$ & $\begin{array}{c}\text { baseline from }{ }^{1} \text {, lower bound from }{ }^{34} \text {, upper } \\
\text { bound is baseline }+10 \%\end{array}$ & 0.10 & -0.02 & -0.02 \\
\hline natural gas price & $\$ \cdot \mathrm{kg}^{-1}$ & 0.253 & $\begin{array}{l}0.198,0.253,0.304 \\
\text { triangular }\end{array}$ & $\begin{array}{c}\text { range is the minimum, average, and maximum } \\
\text { price during } 2010-2019^{35}\end{array}$ & 0.16 & -0.01 & -0.01 \\
\hline gypsum disposal $^{b}$ & $\$ \cdot \mathrm{kg}^{-1}$ & 0 & $\begin{array}{l}-0.0288 \text { to } 0.00776 \\
\text { uniform }\end{array}$ & $\begin{array}{c}\text { lower bound from }{ }^{34} \text {, upper bound the same as } \\
\text { ash disposal }\end{array}$ & -0.14 & -0.05 & -0.04 \\
\hline electricity price & $\$ \cdot \mathrm{kWh}^{-1}$ & 0.070 & $\begin{array}{c}0.067,0.070,0.074 \\
\text { triangular }\end{array}$ & $\begin{array}{c}\text { range is the minimum, average, and maximum } \\
\text { price during } 2010-2019^{35}\end{array}$ & -0.06 & -0.07 & -0.06 \\
\hline \multicolumn{8}{|l|}{ Pretreatment } \\
\hline solid loading & mass $\%$ & $30 \%$ & $\begin{array}{l}25 \%, 30 \%, 40 \% \\
\text { triangular }\end{array}$ & baseline and range from ${ }^{5}$ & 0.05 & 0.09 & 0.07 \\
\hline sulfuric acid loading & $\begin{array}{l}\mathrm{mg} \cdot \mathrm{g}-\mathrm{dry} \\
\text { feedstock }\end{array}$ & 22.1 & $10,22.1,35$, triangular & baseline and range from ${ }^{5}$ & -0.02 & -0.08 & -0.09 \\
\hline glucan-to-glucose conversion & $\%$ of glucan & $9.9 \%$ & $\begin{array}{l}6 \%, 9.9 \%, 12 \% \\
\text { triangular }\end{array}$ & baseline and range from ${ }^{5}$ & -0.04 & -0.02 & -0.02 \\
\hline xylan-to-xylose conversion & $\%$ of xylan & $90 \%$ & $\begin{array}{l}80 \%, 90 \%, 92 \% \\
\text { triangular }\end{array}$ & baseline and range from ${ }^{5}$ & -0.06 & -0.01 & 0.002 \\
\hline
\end{tabular}

a For triangular distributions, the midpoint is the same as the baseline value.

${ }^{\mathrm{b}}$ A negative gypsum disposal price indicates it is sold as a co-product. 
Table S5 (Continued). List of parameters included in the uncertainty analysis.

\begin{tabular}{|c|c|c|c|c|c|c|c|}
\hline \multirow[b]{2}{*}{ Parameter } & \multirow[b]{2}{*}{ Unit } & \multirow[b]{2}{*}{ Baseline } & \multirow[b]{2}{*}{ Distribution } & \multirow[b]{2}{*}{ References } & \multicolumn{3}{|c|}{ Spearman's $\rho$} \\
\hline & & & & & MPSP & GWP $_{100}$ & FEC \\
\hline \multicolumn{8}{|l|}{ Conversion } \\
\hline solid loading & mass $\%$ & $20 \%$ & $\begin{array}{l}17.5 \%, 20 \%, 25 \% \\
\text { triangular }\end{array}$ & baseline and range from ${ }^{5}$ & -0.28 & -0.55 & -0.55 \\
\hline enzyme loading & mg $\cdot g$-glucan ${ }^{-1}$ & 20 & $\begin{array}{l}10,20,30 \\
\text { triangular }\end{array}$ & baseline and range from ${ }^{5}$ & 0.18 & 0.02 & 0.02 \\
\hline saccharification time & $\mathrm{h}$ & 24 & $0,24,56$, triangular & $\begin{array}{l}\text { baseline (midpoint) based on }{ }^{5} \text {, lower and upper bound } \\
\text { are the } 5^{\text {th }} \text { and } 95^{\text {th }} \text { percentiles of data in Table } 53\end{array}$ & 0.03 & 0.001 & $0 . \overline{0}-$ \\
\hline glucan-to-glucose conversion & $\%$ of glucan & $90 \%$ & $\begin{array}{l}75 \%, 90 \%, 95 \% \\
\text { triangular }\end{array}$ & baseline and range from ${ }^{5}$ & -0.19 & -0.09 & -0.08 \\
\hline CSL loading & $g \cdot L^{-1}$ & 10 & $5,10,15$, triangular & baseline and range based on ${ }^{5}$ and Table S3 & 0.02 & 0.09 & 0.06 \\
\hline lactic acid yield & $g \cdot g^{-1}$ sugar & 0.76 & $\begin{array}{l}0.55,0.76,0.93 \\
\text { triangular }\end{array}$ & $\begin{array}{l}\text { lower bound, midpoint (baseline), and upper bound are } \\
\text { the } 5^{\text {th }}, 50^{\text {th }} \text {, and } 95^{\text {th }} \text { percentiles of data in Table } S 3\end{array}$ & -0.80 & -0.54 & -0.49 \\
\hline lactic acid productivity & $g \cdot L^{-1} \cdot h^{-1}$ & 0.89 & $\begin{array}{l}0.33,0.89,1.66 \\
\text { triangular }\end{array}$ & $\begin{array}{l}\text { lower bound, midpoint (baseline), and upper bound are } \\
\text { the } 5^{\text {th }}, 50^{\text {th }} \text {, and } 95^{\text {th }} \text { percentiles of data in Table } S 3\end{array}$ & -0.08 & -0.02 & -0.02 \\
\hline acetic acid yield & $g \cdot g^{-1}$ sugar & 0.07 & $\begin{array}{l}0.004,0.07,0.32 \\
\text { triangular }\end{array}$ & $\begin{array}{l}\text { lower bound, midpoint (baseline), and upper bound are } \\
\text { the } 5^{\text {th }}, 50^{\text {th }} \text {, and } 95^{\text {th }} \text { percentiles of data in Table } S 3\end{array}$ & 0.07 & 0.06 & 0.05 \\
\hline inoculum ratio & $\%$ & $7 \%$ & $\begin{array}{l}5 \%, 7 \%, 10 \% \\
\text { triangular }\end{array}$ & baseline and range based on ${ }^{5}$ and Table $\mathbf{S 3}$ & -0.03 & -0.01 & -0.003 \\
\hline seed train yield & $\%$ of fermenter & $95 \%$ & $\begin{array}{l}90 \%, 95 \%, 100 \% \\
\text { triangular }\end{array}$ & baseline based on ${ }^{5}$, lower bound assumed & 0.02 & 0.02 & 0.02 \\
\hline \multicolumn{8}{|l|}{ Separation } \\
\hline acidulation time & $\mathrm{h}$ & 1 & $\begin{array}{l}0.9,1.0,1.1 \\
\text { triangular }\end{array}$ & baseline from BioSTEAM mix tank & 0.07 & 0.07 & 0.07 \\
\hline gypsum separation & $\%$ & $99.5 \%$ & $\begin{array}{l}95 \%, 99.5 \%, 100 \% \\
\text { triangular }\end{array}$ & baseline based on ${ }^{19}$, lower bound assumed & 0.02 & -0.01 & -0.02 \\
\hline esterification conversion & $\%$ & $19 \%$ & $\begin{array}{l}17.1 \%, 19 \%, 20.9 \% \\
\text { triangular }\end{array}$ & baseline simulated using kinetic model from $7,36,37$ & -0.17 & -0.27 & -0.27 \\
\hline hydrolysis conversion & $\%$ & $80 \%$ & $\begin{array}{l}72 \%, 80 \%, 88 \% \\
\text { triangular }\end{array}$ & baseline from ${ }^{37}$ & -0.10 & -0.09 & -0.08 \\
\hline \multicolumn{8}{|l|}{ Facilities } \\
\hline boiler efficiency & $\%$ & $80 \%$ & $72-88 \%$, uniform & baseline from 1,5 & -0.19 & -0.55 & -0.61 \\
\hline
\end{tabular}




\section{References}

(1) Davis, R. E.; Grundl, N. J.; Tao, L.; Biddy, M. J.; Tan, E. C.; Beckham, G. T.; Humbird, D.; Thompson, D. N.; Roni, M. S. Process Design and Economics for the Conversion of Lignocellulosic Biomass to Hydrocarbon Fuels and Coproducts: 2018 Biochemical Design Case Update; NREL/TP-5100-71949; NREL, 2018. https://doi.org/10.2172/1483234.

(2) Wang, Y.; Tashiro, Y.; Sonomoto, K. Fermentative Production of Lactic Acid from Renewable Materials: Recent Achievements, Prospects, and Limits. Journal of Bioscience and Bioengineering 2015, 119 (1), 10-18. https://doi.org/10.1016/j.jbiosc.2014.06.003.

(3) IHS Markit. Chemical Economics Handbook - Lactic Acid, Its Salts and Esters; 2018.

(4) Kuo, Y.-C.; Yuan, S.-F.; Wang, C.-A.; Huang, Y.-J.; Guo, G.-L.; Hwang, W.-S. Production of Optically Pure L-Lactic Acid from Lignocellulosic Hydrolysate by Using a Newly Isolated and d-Lactate Dehydrogenase Gene-Deficient Lactobacillus Paracasei Strain. Bioresource Technology 2015, 198, 651-657. https://doi.org/10.1016/j.biortech.2015.09.071.

(5) Humbird, D.; Davis, R.; Tao, L.; Kinchin, C.; Hsu, D.; Aden, A.; Schoen, P.; Lukas, J.; Olthof, B.; Worley, M.; Sexton, D.; Dudgeon, D. Process Design and Economics for Biochemical Conversion of Lignocellulosic Biomass to Ethanol: Dilute-Acid Pretreatment and Enzymatic Hydrolysis of Corn Stover, Technical Report NREL/TP-5100-47764; National Renewable Energy Lab (NREL), 2011.

(6) Gezae Daful, A.; Görgens, J. F. Techno-Economic Analysis and Environmental Impact Assessment of Lignocellulosic Lactic Acid Production. Chemical Engineering Science 2017, 162, 53-65. https://doi.org/10.1016/j.ces.2016.12.054.

(7) Pereira, C. S. M.; Pinho, S. P.; Silva, V. M. T. M.; Rodrigues, A. E. Thermodynamic Equilibrium and Reaction Kinetics for the Esterification of Lactic Acid with Ethanol Catalyzed by Acid Ion-Exchange Resin. Ind. Eng. Chem. Res. 2008, 47 (5), 1453-1463. https://doi.org/10.1021/ie071220p.

(8) Mandegari, M. A.; Farzad, S.; van Rensburg, E.; Görgens, J. F. Multi-criteria Analysis of a Biorefinery for Co-production of Lactic Acid and Ethanol from Sugarcane Lignocellulose. Biofuels, Bioprod. Bioref. 2017, 11 (6), 971-990. https://doi.org/10.1002/bbb.1801.

(9) Mandegari, M.; Farzad, S.; Görgens, J. F. A New Insight into Sugarcane Biorefineries with Fossil Fuel Co-Combustion: Techno-Economic Analysis and Life Cycle Assessment. Energy Conversion and Management 2018, 165, 76-91. https://doi.org/10.1016/j.enconman.2018.03.057.

(10) Alves De Oliveira, R.; Alexandri, M.; Komesu, A.; Venus, J.; Vaz Rossell, C. E.; Maciel Filho, R. Current Advances in Separation and Purification of Second-Generation Lactic Acid.

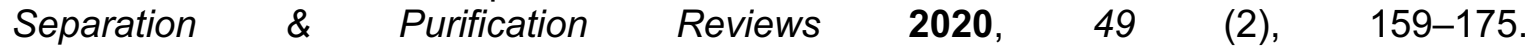
https://doi.org/10.1080/15422119.2019.1590412.

(11) Komesu, A.; Wolf Maciel, M. R.; Maciel Filho, R. Separation and Purification Technologies for Lactic Acid - A Brief Review. BioResources 2017, 12 (3), 6885-6901.

(12) Grossman, G.; Sonin, A. A. Membrane Fouling in Electrodialysis: A Model and Experiments. Desalination 1973, 12 (1), 107-125. https://doi.org/10.1016/S0011-9164(00)80178-2.

(13) Shi, L.; Xie, S.; Hu, Z.; Wu, G.; Morrison, L.; Croot, P.; Hu, H.; Zhan, X. Nutrient Recovery from Pig Manure Digestate Using Electrodialysis Reversal: Membrane Fouling and Feasibility of Long-Term Operation. Journal of Membrane Science 2019, 573, 560-569. https://doi.org/10.1016/j.memsci.2018.12.037.

(14) Baral, N. R.; Kavvada, O.; Mendez-Perez, D.; Mukhopadhyay, A.; Lee, T. S.; Simmons, B. A.; Scown, C. D. Techno-Economic Analysis and Life-Cycle Greenhouse Gas Mitigation Cost of Five Routes to Bio-Jet Fuel Blendstocks. Energy Environ. Sci. 2019, 12 (3), 807824. https://doi.org/10.1039/C8EE03266A. 
(15) Liu, G.; Sun, J.; Zhang, J.; Tu, Y.; Bao, J. High Titer L-Lactic Acid Production from Corn Stover with Minimum Wastewater Generation and Techno-Economic Evaluation Based on Aspen plus Modeling. Bioresource Technology 2015, 198, 803-810. https://doi.org/10.1016/j.biortech.2015.09.098.

(16) Han, X.; Hong, F.; Liu, G.; Bao, J. An Approach of Utilizing Water-Soluble Carbohydrates in Lignocellulose Feedstock for Promotion of Cellulosic I-Lactic Acid Production. J. Agric. Food Chem. 2018, 66 (39), 10225-10232. https://doi.org/10.1021/acs.jafc.8b03592.

(17) Wei, C.; Liu, G.; Zhang, J.; Bao, J. Elevating Fermentation Yield of Cellulosic Lactic Acid in Calcium Lactate Form from Corn Stover Feedstock. Industrial Crops and Products 2018, 126, 415-420. https://doi.org/10.1016/j.indcrop.2018.10.041.

(18) Gezae Daful, A.; Görgens, J. F. Techno-Economic Analysis and Environmental Impact Assessment of Lignocellulosic Lactic Acid Production. Chemical Engineering Science 2017, 162, 53-65. https://doi.org/10.1016/j.ces.2016.12.054.

(19) Aden, A.; Ruth, M.; Ibsen, K.; Jechura, J.; Neeves, K.; Sheehan, J.; Wallace, B.; Montague, L.; Slayton, A.; Lukas, J. Process Design Report for Stover Feedstock: Lignocellulosic Biomass to Ethanol Process Design and Economics Utilizing Co-Current Dilute Acid Prehydrolysis and Enzymatic Hydrolysis for Corn Stover; NREL/TP-510-32438; National Renewable Energy Lab (NREL), 2002. https://doi.org/10.2172/1218326.

(20) Zhang, Z.; Xie, Y.; He, X.; Li, X.; Hu, J.; Ruan, Z.; Zhao, S.; Peng, N.; Liang, Y. Comparison of High-Titer Lactic Acid Fermentation from NaOH- and NH3-H2O2-Pretreated Corncob by Bacillus Coagulans Using Simultaneous Saccharification and Fermentation. Sci Rep 2016, 6. https://doi.org/10.1038/srep37245.

(21) Zhang, Y.; Chen, X.; Luo, J.; Qi, B.; Wan, Y. An Efficient Process for Lactic Acid Production from Wheat Straw by a Newly Isolated Bacillus Coagulans Strain IPE22. Bioresource Technology 2014, 158, 396-399. https://doi.org/10.1016/j.biortech.2014.02.128.

(22) Maas, R. H. W.; Bakker, R. R.; Jansen, M. L. A.; Visser, D.; de Jong, E.; Eggink, G.; Weusthuis, R. A. Lactic Acid Production from Lime-Treated Wheat Straw by Bacillus Coagulans: Neutralization of Acid by Fed-Batch Addition of Alkaline Substrate. Appl Microbiol Biotechnol 2008, 78 (5), 751-758. https://doi.org/10.1007/s00253-008-1361-1.

(23) Hu, J.; Zhang, Z.; Lin, Y.; Zhao, S.; Mei, Y.; Liang, Y.; Peng, N. High-Titer Lactic Acid Production from NaOH-Pretreated Corn Stover by Bacillus Coagulans LA204 Using FedBatch Simultaneous Saccharification and Fermentation under Non-Sterile Condition. $\begin{array}{llll}\text { Bioresource Technology 2015, 251-257. } & \text { 20182, }\end{array}$ https://doi.org/10.1016/j.biortech.2015.02.008.

(24) Wang, Y.; Wang, M.; Cai, D.; Wang, B.; Wang, Z.; Qin, P.; Tan, T. Efficient L-Lactic Acid Production from Sweet Sorghum Bagasse by Open Simultaneous Saccharification and $\begin{array}{llllll}\text { Fermentation. } & \text { 2016, } & 6 & \text { (42), } & \text { 35771-35777. }\end{array}$ https://doi.org/10.1039/C6RA04538C.

(25) Eom, I.-Y.; Oh, Y.-H.; Park, S. J.; Lee, S.-H.; Yu, J.-H. Fermentative L-Lactic Acid Production from Pretreated Whole Slurry of Oil Palm Trunk Treated by Hydrothermolysis and Subsequent Enzymatic Hydrolysis. Bioresource Technology 2015, 185, 143-149. https://doi.org/10.1016/j.biortech.2015.02.060.

(26) Hu, J.; Lin, Y.; Zhang, Z.; Xiang, T.; Mei, Y.; Zhao, S.; Liang, Y.; Peng, N. High-Titer Lactic Acid Production by Lactobacillus Pentosus FL0421 from Corn Stover Using Fed-Batch Simultaneous Saccharification and Fermentation. Bioresource Technology 2016, 214, 7480. https://doi.org/10.1016/j.biortech.2016.04.034.

(27) Zhang, Y.; Vadlani, P. V.; Kumar, A.; Hardwidge, P. R.; Govind, R.; Tanaka, T.; Kondo, A. Enhanced D-Lactic Acid Production from Renewable Resources Using Engineered Lactobacillus Plantarum. Appl Microbiol Biotechnol 2016, 100 (1), 279-288. https://doi.org/10.1007/s00253-015-7016-0. 
(28) Hama, S.; Mizuno, S.; Kihara, M.; Tanaka, T.; Ogino, C.; Noda, H.; Kondo, A. Production of D-Lactic Acid from Hardwood Pulp by Mechanical Milling Followed by Simultaneous Saccharification and Fermentation Using Metabolically Engineered Lactobacillus Plantarum. Bioresource Technology 2015, 187, 167-172. https://doi.org/10.1016/j.biortech.2015.03.106.

(29) Cui, F.; Li, Y.; Wan, C. Lactic Acid Production from Corn Stover Using Mixed Cultures of Lactobacillus Rhamnosus and Lactobacillus Brevis. Bioresource Technology 2011, 102 (2), 1831-1836. https://doi.org/10.1016/j.biortech.2010.09.063.

(30) Zhao, W.; Sun, X.; Wang, Q.; Ma, H.; Teng, Y. Lactic Acid Recovery from Fermentation Broth of Kitchen Garbage by Esterification and Hydrolysis Method. Biomass and Bioenergy 2009, 33 (1), 21-25. https://doi.org/10.1016/j.biombioe.2008.04.010.

(31) Vaidya, A. N.; Pandey, R. A.; Mudliar, S.; Kumar, M. S.; Chakrabarti, T.; Devotta, S. Production and Recovery of Lactic Acid for Polylactide-An Overview. Critical Reviews in Environmental Science and Technology 2005, 35 (5), 429-467. https://doi.org/10.1080/10643380590966181.

(32) Roni, M. S.; Hartley, D. S.; Griffel, M.; Hu, H.; Nguyen, Q. A.; Cai, H.; Thompson, D. N. Herbaceous Feedstock 2018 State of Technology Report; INL/EXT-18-51654-Rev000; Idaho National Lab. (INL), Idaho Falls, ID (United States), 2020. https://doi.org/10.2172/1615147.

(33) U.S. Bureau of Labor Statistics. Producer Price Index by Commodity for Chemicals and Allied Products: Sulfuric Acid https://fred.stlouisfed.org/series/WPU0613020T1 (accessed Jul 31, 2020).

(34) National Minerals Information Center. Mineral Commodity Summaries 2020; U.S. Geological Survey, 2020.

(35) U.S. Energy Information Administration. Annual Energy Outlook https://www.eia.gov/outlooks/aeo/ (accessed May 22, 2019).

(36) Zhang, Y.; Ma, L.; Yang, J. Kinetics of Esterification of Lactic Acid with Ethanol Catalyzed by Cation-Exchange Resins. Reactive and Functional Polymers 2004, 61 (1), 101-114. https://doi.org/10.1016/j.reactfunctpolym.2004.04.003.

(37) Delgado, P.; Sanz, M. T.; Beltrán, S. Kinetic Study for Esterification of Lactic Acid with Ethanol and Hydrolysis of Ethyl Lactate Using an Ion-Exchange Resin Catalyst. Chemical Engineering Journal 2007, 126 (2-3), 111-118. https://doi.org/10.1016/j.cej.2006.09.004. 